Külgazdaság, LXV. évf., 2021. szeptember-október (3-31. o.)

\title{
A külföldi közvetlentőke-befektetés hatása a magyar gazdaságra: küldő ország szerinti heterogenitás TŐKÉS LÁSZLÓ*
}

Az 1989-es rendszerváltás után Magyarország is bekapcsolódott a gazdasági globalizáció folyamatába, amelynek fontos komponense a határokon átivelö tökeáramlás. Magyarország rövid idön belül a külföldi közvetlentöke-befektetések (foreign direct investments - FDI) vonzó célpontjává vált. Mára a külföldi tőke súlya és szerepe a magyar gazdaságban megkérdöjelezhetetlen. Az FDI makrogazdaságra gyakorolt hatását hosszú ideje elemzi a közgazdasági szakirodalom. A kutatások alapján mára általánosan elfogadott, hogy az FDI jótékony hatással lehet a gazdasági növekedésre. Ennek egyik fö eszköze a technológiai transzmisszió, azaz a külföldi tökebefektetök fejlett technológiát és tudást hoznak magukkal és alkalmaznak, ami képes serkenteni a fogadó ország gazdaságát. Ennek alapján az várható, hogy a fejlettebb országokból érkezö töke nemzetgazdaságra gyakorolt hatása azért erőteljesebb, mert az importált technológia és tudás magasabb színvonalú. A tanulmány ezt a hipotézist vizsgálja ún. autoregressziv osztott késleltetésü kointegrációs modell segítségével, 2001 és 2018 közötti magyar makrogazdasági adatok alapján. Az eredmények szerint a tanulmány hipotézise elfogadható.

Journal of Economic Literature (JEL) kód: F210, F430.

Kulcsszavak: FDI, ARDL, gazdasági növekedés, heterogenitás.

* Tőkés László egyetemi tanársegéd, Budapesti Corvinus Egyetem, Közgazdaságtan Intézet, laszlo.tokes@uni-corvinus.hu

A kézirat első változata 2021. április 21-én érkezett szerkesztőségünkbe.

https://doi.org/10.47630/KULG.2021.65.9-10.3 
Abstract

\section{The effects of inward foreign direct investments on Hungarian economic growth - heterogeneity by country of origin \\ LÁSZLÓ TŐKÉS}

After the regime change in 1989, Hungary has been involved in globalization whose one of the most important component are international capital flows. Within a rather short period of time, Hungary has become an attractive target for foreign direct investments (FDI). By now, the weight and role of foreign capital in the Hungarian economy is beyond question. The effects of FDI on the recipient country's economy have been analysed for a long time in the relevant economic literature. The major conclusion is that FDI can foster economic growth. The main channel of the positive effects is technology transfer: FDI investors bring advanced technology and knowledge that can improve the recipient country's economic performance. Accepting the existence of the transmission channel, it is assumed that the more developed the investor country, the stronger the effect is, since an investor of a developed country can bring more advanced technology and know-how. In this paper, this hypothesis was tested with the help of the so-called autoregressive distributive lag model on Hungarian macro-level data ranging from 2001 to 2018. The results confirm our hypothesis.

Journal of Economic Literature (JEL) codes: F210, F430.

Keywords: FDI, ARDL, economic growth, heterogeneity.

\section{Bevezetés}

A globalizáció és a gazdaságok határokon átívelö összefonódása a 20. század végén nagy lendületet vett, és azóta is a világgazdasági folyamatok egyik számottevő tényezője. Ez a globális szintủ nemzetközi gazdasági integráció számos folyamatban jut kifejezésre. Ezek egyik jelentős összetevője a tőke, azon belül is a közvetlen tőke országokon átívelő áramlása. Az OECD definíciója alapján a külföldi közvetlentőke-befektetés „(...) a határon átívelő beruházás egy fajtája, amelyet egy gazdaság rezidens vállalata (közvetlen befektetö) hajt végre annak az érdekében, hogy egy másik gazdaság rezidens vállalatában (...) tartós érdekeltséget szerezzen" (OECD, 2008:17). Az 1989-es rendszerváltást követően Magyarország is bekapcsolódott a nemzetközi folyamatokba, és a többi fejlődő és tranzíciós országhoz hasonlóan a külföldi közvetlentőke-befektetések egyik célpontjává vált.

Az 1. ábra a Magyarországra áramló külföldi közvetlentőke-forgalom időbeli alakulását mutatja a GDP és a bruttó állóeszköz-felhalmozás arányában. 1990 és 1995 között egy ingadozás melletti felfutó trendet láthattunk, amelyet trendszerü 
csökkenés követett 2010-ig, szintén erős volatilitás mellett. Majd 2011-ben és 2012ben igen erős emelkedés volt tapasztalható, mindkét idősor korábbi rekordértéke fölé növekedett: a GDP-arányos FDI értéke meghaladta a 11 százalékot (a korábbi csúcspont 1995-ben volt, minimálisan 11 százalék alatt), a bruttó állóeszköz-felhalmozás arányában mért adat pedig majdnem elérte a 60 százalékot (jóval meghaladva az 1995. évi 50 százalékos rekordértéket). Ezt követően mindkét idősor zuhanást mutatott, 2015-ben a GDP-arányos mutató -12 százalékra, az állóeszköz-felhalmozás arányában számolt indikátor pedig -52 százalékra esett vissza. Ezt korrekció követte, mindkét mutató 2017-ben került vissza ismét a pozitív tartományba.

\section{A Magyarországra áramló külföldi közvetlentőke-forgalom a GDP és a bruttó állóeszköz-felhalmozás arányában}
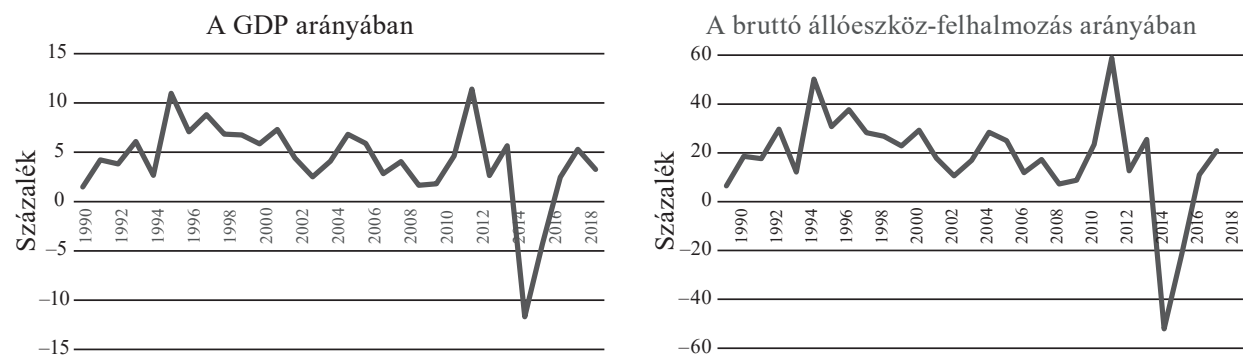

Forrás: Saját szerkesztés az UNCTAD Stat adatai alapján.

Ha aggregáljuk a bemutatott áramlásokat, akkor látható, hogy Magyarországon 2018-ban igen nagy külföldi tőkeállomány volt jelen, értéke 26910 milliárd forintra rúgott, ami az az évi magyar bruttó hazai termék 63 százalékának felelt meg. A külföldi közvetlen tőke szerepe tehát a magyar gazdaságban jelentősnek tekinthető.

Éppen ezért a téma elemzése nem pusztán elméleti, hanem szakpolitikai szempontból is fontos lehet, ugyanis a világ országainak kormányzatai számos eszközzel próbálnak hatni a közvetlentőke-befektetések áramlására. A rendszerváltás óta Magyarország mindenkori kormányzata különböző eszközökkel támogatja a külföldi közvetlentőke-befektetéseket. Az 1990-es évek befektetésösztönzését vizsgálva írta Antalóczy és Sass (2000:489) a következőt: „Magyarország a beruházási ösztönzök komplex rendszerét alkalmazza, amelyek célja nemcsak a külföldi tőkebefektetések vonzása, hanem azok szektorális és regionális terelése is." Szintén a 
rendszerváltást követő másfél évtized eszközeit részletezi Antalóczy és Sass (2003). Később, bár megváltozott elvek alapján, de továbbra is jelentős kormányzati ösztönzéspolitikát láthatunk, ezt részletezi például Sass és Kalotay (2012). A mindenkori magyar kormányzatok eltérő mértékben, eltérő elvek alapján vetettek be pénzügyi, költségvetési és egyéb ösztönzőket a külföldi közvetlentőke-befektetések Magyarországra vonzása érdekében.

Ez a tanulmány azt elemzi, hogy a külföldi közvetlentőke-befektetések gazdasági növekedésre gyakorolt hatása függ-e attól, honnan érkezik az FDI: termelékeny vagy kevésbé termelékeny országból. A közgazdasági intuíció és az irodalom korábbi megállapításai alapján az várható, hogy ez számít. Az első részben az empirikus munkákra koncentrálva tekintem át a releváns szakirodalmat. A második részben az alkalmazott módszertant, a harmadikban pedig a felhasznált adatokat mutatom be. A negyedik rész tartalmazza az eredményeket, az ötödik pedig az összefoglalást és a következtetéseket.

\section{A releváns szakirodalom áttekintése}

A modern növekedéselmélet sokféle magyarázatot ad a gazdasági növekedésre, számos olyan tényezőt említ, amelyek befolyásolják a gazdaságok hosszú távú növekedését. Az egyik legfontosabb ilyen tényező a technológia. Robert Solow (1956) úttörő cikkében az extenzív növekedést vizsgálta, és elemezte a tőkeállomány, valamint a munkaerö-állomány növekedésre gyakorolt hatását. Modelljének egyfajta kiterjesztéseként ugyanakkor már ő is megemlítette a technológia szerepét, amely viszont csupán exogén tényezőként jelent meg nála. Modelljében a külföldi közvetlentőke-befektetést nem tárgyalta. Mivel az FDI egyfajta speciális tőkefelhalmozásként is értelmezhető, a modell implikációja szerint az FDI okozhat extenzív növekedést. Később az endogén növekedéselmélet már inkább fókuszált a technológia szerepére a gazdasági növekedésben, lásd például Romer (1986), Lucas (1988) és Rebelo (1991) írásait. E modellek külföldi tőkére megfogalmazható implikációi alapján az FDI képes gazdasági növekedést előidézni az új technológiák fogadó országba történő bevitele és ottani elterjedése, vagyis a tovagyűrüző hatásai révén.

Összefoglalásként megállapítható, hogy mind az exogén, mind az endogén növekedéselméletben találhatók olyan megállapítások, amelyek alkalmazhatók a külföldi közvetlentőke-befektetésekre: az FDI a tőkefelhalmozás révén is képes növelni a fogadó ország teljesítményét, valamint - és ami fontosabb - a technológiatranszfer révén is jótékony hatással van arra. 
Az egyik legelső elméleti munka Koizumi és Kopecky (1977) nevéhez füződik. A szerzőpáros egy kis nyitott gazdaság modelljében vizsgálta a külföldi tőkéhez kapcsolódó technológiatranszfert, és mutatott rá annak kedvező hatásaira. Szintén a korai munkák közé sorolható a Findlay (1978) által bemutatott dinamikus modell, amelyben a szerző arra a következtetésre jutott, hogy a külföldi közvetlen töke a technológiai fejlődést elősegítve fejti ki jótékony hatását a gazdasági növekedésre. Borensztein et al. (1998) modellje pedig a fejlődő országokat tárgyalva mutatott rá arra, hogy azok növekedése részben a technológiai felzárkózásból fakad. A konvergenciát gyorsíthatja, ha a fejlett országok FDI révén adják át a fejlett technológiát a fejlődő országnak. Azóta is a technológiai csatorna dominanciájának hangsúlyozása jellemzi az irodalmat. Általános megfigyelés, hogy a multinacionális vállalatok jelentős erőforrásokat fordítanak kutatás-fejlesztésre, aminek következtében fejlett technológiával rendelkeznek, és termelékenyebbek. Ezt a tudást képesek az őket fogadó országokba „exportálni” (Borensztein et al., 1998). Ez a tudás pedig utána vertikális és horizontális kapcsolatok, a munkavállalók mozgása, illetve a kutatás-fejlesztés internalizációja révén gyürüzik tovább a fogadó országban (OECD, 2002).

A tanulmány motivációját ez adja: a technológiatranszfer szerepét vizsgálom empirikus eszközök segítségével. Hipotézisem szerint a termelékenyebb, technológiailag fejlettebb országokból érkező tőke a technológiatranszfer bemutatott szerepe alapján nagyobb pozitív hatást gyakorol a növekedésre, mint a kevésbé termelékeny országból érkező tőke.

A relatíve szűkös elméletivel szemben bőséges empirikus irodalom foglalkozik a külföldi közvetlen tőke és a gazdasági növekedés kapcsolatával. ${ }^{1}$ Az eredmények megoszlanak, teljesen egyértelmủ konklúzió nem fogalmazható meg. Számos kutatás arra az eredményre jutott, hogy a külföldi közvetlen tőke jótékony hatással van a gazdasági növekedésre, lásd például Balasubramanyam et al. (1996), Baldwin et al. (2005), Choe (2003), De Gregorio (1992), Dhrifi (2015), Gurgul \& Lach (2014), Iamsiraroj (2016), Iamsiraroj és Ulubasoglu (2015), Li \& Liu (2005), Mahmoodi \& Mahmoodi (2016), Nair-Reichert \& Weinhold (2001), Pegkas (2015), Saleem et al. (2020) és Sylwester (2005) munkáit.

Ugyanakkor a pozitív hatásokat erős heterogenitás és különböző feltételek árnyalják. Nair-Reichert és Weinhold (2001) rámutat, hogy az eredmények nagyszámú országspecifikus tulajdonságtól függhetnek, ezért problémás lehet az országokat

\footnotetext{
${ }^{1}$ Az irodalomáttekintésben a vállalati adatokat használó kutatásokkal nem foglalkozom.
} 
homogén csoportként kezelni és elemezni. Például Alvarado és munkatársai (2017) latin-amerikai országokat vizsgálva jövedelemtől függő heterogenitást fedeztek fel: magas jövedelmủ országokban szignifikáns pozitív hatást találtak, a közepes jövedelmủ országoknál nincs hatás, az alacsony jövedelmủ államokban pedig szignifikáns negatív hatást gyakorol az FDI a növekedésre. Alfaro et al. (2004) szerint az FDI gazdasági növekedésre gyakorolt hatása kérdéses. Azok az országok azonban, amelyek fejlett pénzügyi piacokkal rendelkeznek, ki tudják használni az FDI áldásos hatásait. Hermes és Lensink (2003) szintén a pénzpiacok fejlettségének szerepét hangsúlyozta. A pénzügyi közvetítő rendszer kockázatcsökkentő szerepe révén képes lehet olyan új beruházások megvalósulási valószínüségét növelni, amelyek alkalmasak az idegen technológiák befogadására és lemásolására. Borensztein et al. (1998) szerint az FDI a technológiatranszfer fontos eszköze, ugyanakkor a lehetőségeket csak akkor lehet kiaknázni, ha a fogadó ország humán tőkéje meghalad egy bizonyos szintet, mivel az idegen technológia alkalmazásához emberi tudás és képzettség is szükséges. Ezzel szemben Gui-Diby (2014) eredményei alapján a humán tőke nem releváns tényező, viszont a szerző időbeni heterogenitást mutatott ki: 1980 és 1995 között afrikai országok paneljén az FDI növekedésre gyakorolt hatása negatív, míg az 1995 és 2009 közötti periódusban pozitív volt. Balasubramanyam és munkatársai (1996) arra mutattak rá, hogy az FDI áldásos hatásai leginkább azokban az országokban jelentkeznek, amelyek exportorientált külkereskedelmi politikát folytatnak. Batten és Vo (2009) azt mutatta ki, hogy a fogadó ország gazdasági környezetének bizonyos elemei milyen mértékben teszik lehetővé az FDI pozitív hatásainak az érvényre jutását. A környezeti tényezők között a populáció iskolázottágát, a külkereskedelmi nyitottságot, a pénzügyi piacok fejlettségét és a népességnövekedés ütemét azonosította. Bengoa és Sanchez-Robles (2003) szerint az általuk vizsgált tizennyolc latin-amerikai ország közül csak azok tudtak hosszú távon profitálni a beáramló külföldi közvetlen tőkéből, amelyekben rendelkezésre állt a megfelelő szintű humán tőke, egyértelmű volt a gazdasági stabilitás és a piacok kellően liberalizáltak voltak. Az eddig áttekintett szakirodalmi források szerint az FDI kimutatott pozitív hatásai nagyszámú tényezőtől függenek.

Más források, így Azman-Saini et al. (2010), valamint Herzer (2012) nem találtak szignifikáns hatást, vagy azt igazolták, hogy az FDI negatív hatással van a növekedésre.

Kérdés: az eredményekben, azaz a hatás meglétében, irányában és erősségében tapasztalható heterogenitás nem annak tulajdonítható-e, hogy a tanulmányok nagy része igen sok országból álló mintát vizsgált (,,bucket approach”), és a min- 
tában szereplő országok több szempontból is igen különbözőek voltak. Megoldás lehet kisebb és homogénebb minta kiválasztása. Így homogénebb mintát alkotnak a közép- és kelet-európai országok. Ez a mintaszúkítés sem eredményez azonban erősebb konklúziót, a tanulmányok eredményei itt sem konvergálnak teljes mértékben. Campos és Kinoshita (2002) huszonöt, Ghergina és munkatársai (2019) tizenegy, Gurgul és Lach (2014) tíz, Petr és Bal-Domanska (2016) nyolc, Vojtovič és munkatársai (2019) pedig tizenegy régióbeli országot vizsgálva állapították meg, hogy a külföldi közvetlentőke-befektetés szignifikáns és pozitív hatást gyakorol a gazdasági növekedésre. Barrell és Holland (2000) három, Bijsterbosch és Kolasa (2009) pedig nyolc ország iparági adatait elemezve igazolta, hogy az FDI növeli a fogadó ország és/vagy iparág termelékenységét. Kornecki (2008) az FDI-állomány és a GDP között erős pozitív korrelációt mutatott ki öt ország adatainak elemzése alapján. Bacic és munkatársai (2004) ugyanakkor egy tizenegy közép- és kelet-európai tranzíciós országból álló mintán nem találtak szignifikáns hatást. Tang (2015) sem bizonyított hatást az Európai Unió tizenöt tagországa esetében. Mencinger (2003) nyolc országot vizsgálva következtetett arra, hogy az FDI kifejezetten negatív és szignifikáns hatást gyakorol a növekedésre. Simionescu et al. (2017) szerint a visegrádi együttműködés országai (Csehország, Lengyelország, Magyarország és Szlovákia) és Románia közül csak Szlovákia gazdasági növekedésére nem gyakorolt kedvező hatást az FDI.

Az eredmények egy homogénebb mintán sem konvergálnak. Az országspecifikus tényezők implicit figyelembevételének egyik módja az országszintü kutatások lefolytatása. Ilyenből jegyzett helyen és angol nyelven igen kevés jelent meg az elmúlt néhány évben. Az 1. táblázat a 2016 után publikált, jelentősebb idézettségủ cikkek fö következtetéseit tartalmazza.

Az elmúlt néhány évben egyországos kutatások a témában döntően a fejlődő országokra születtek, miként az az 1. táblázatból kivehető. A módszertant tekintve korszerübb eszközöket alkalmaztak, amilyen az ebben a tanulmányban is felhasznált ARD-modell és intervallumhatár-teszt. Az eredmények ugyan nem teljesen egyöntetűek, de többnyire az FDI pozitív hosszú távú hatását igazolták. 
Egy országra vonatkozó tanulmányok és fö következtetésük

\begin{tabular}{llllll}
\hline Cikk & \multicolumn{1}{c|}{$\begin{array}{c}\text { Vizsgált } \\
\text { ország }\end{array}$} & $\begin{array}{c}\text { Vizsgált } \\
\text { időszak }\end{array}$ & Módszertan & $\begin{array}{c}\text { FDI-növekedésre } \\
\text { gyakorolt hatása }\end{array}$ \\
\hline Adams et al., 2017 & Szenegál & $1970-2014$ & ARDL & inszignifikáns \\
Bouchoucha \& Ali, 2019 & Tunézia & $1980-2015$ & ARDL & pozitív \\
Bouchoucha \& Sayef, 2019 & Tunézia & $1976-2017$ & ARDL & negatív \\
Carbonell \& Werner, 2018 & Spanyolország & $1984-2010$ & ARDL & inszignifikáns \\
Choi \& Baek, 2017 & India & $1978-2010$ & CVAR & pozitív \\
Durmaz, 2017 & Törökország & $1977-2011$ & ARDL & pozitív \\
Gungor \& Ringim, 2017 & Nigéria & $1980-2015$ & VECM & pozitív \\
$\begin{array}{l}\text { Phouthakannha \& Eungoo, } \\
\text { 2019 }\end{array}$ & Laosz & $1993-2015$ & Johansen- & kointegráció & pozitív \\
Sirag et al., 2018 & Szudán & $1970-2014$ & FMOLS, & pozitív \\
Sothan \& Zhang, 2017 & Kambodzsa & $1980-2014$ & VECM & pozitív \\
Soylu, 2019 & Lengyelország & $1992-2016$ & ARDL & pozitív \\
Sultanuzzaman et al., 2018 & Srí Lanka & $1980-2016$ & ARDL & pozitív \\
Zandile \& Phiri, 2019 & Burkina Faso & $1970-2017$ & ARDL & inszignifikáns \\
\hline
\end{tabular}

Megjegyzés: Az utolsó oszlopban az FDI gazdasági növekedésre gyakorolt hosszú távú hatására vonatkozó eredmények találhatók.

Forrás: Saját szerkesztés forrásgyüjtés és -elemzés alapján.

Magyarországra vonatkozó, rigorózus ökonometriai elemzés a témában igen kevés született. Gál (2019) a magyarországi megyék 2000 és 2018 közötti adatait használva vizsgálta az FDI növekedésre gyakorolt hatását. A szerző oksági vizsgálatokkal és panelregressziós elemzésekkel mutatott rá, hogy a Magyarországra áramló külföldi közvetlen tőkének nincs szignifikáns pozitív hatása a GDP alakulására. Balatoni és Pitz (2012) 1995 és 2010 közötti adatokon, más kutatások eredményeit is felhasználva bizonyította, hogy a vizsgált időszak 2,3 százalékos átlagos éves növekedési üteméből 0,69-0,89 százalékot magyarázott a külföldi közvetlen tőke beáramlása. A hatás két csatornán keresztül érvényesült: az FDI többlettőkét biztosított (zöldmezős beruházások), és javította a termelékenységet (közvetlenül, a felvásárolt cégeken keresztül, valamint közvetve is, tovagyürüző hatások révén). Antalóczy és 
Sass (2005) erős pozitív korrelációt talált az FDI és a GDP nagysága és növekedése között regionális és megyei szinten. Bár a szerzők valószínűsítik, hogy oksági kapcsolat is van az FDI és a GDP alakulása között, ökonometriai elemzés hiányában ez csupán hipotézis. A pozitív eredményeket némiképp árnyalja Lengyel és Varga (2018) tanulmánya. A szerzőpáros magyar adatokon végzett térbeli elemzést, és jutott arra a következtetésre, hogy a külföldi közvetlentőke-befektetés önmagában, más endogén és permanens módon jelentkező növekedési tényezők hiányában nem okoz hosszú távú, fenntartható gazdasági növekedést. Gál és munkatársai (2016) három ágazat (üzleti szolgáltatások, pénzügyi szolgáltatások, valamint információs és kommunikációs technológiai [IKT] szolgáltatások) adatait vizsgálta, és az exportra, valamint a foglalkoztatottságra gyakorolt hatásokat mérte. A szerzők eredményei vegyesek: az üzleti szolgáltatások esetében az FDI jótékony hatást gyakorolt az exportra és a foglalkoztatottságra is, míg az IKT-szolgáltatások esetében elsősorban az exportra, a pénzügyi szolgáltatások esetén pedig csak a foglalkoztatottságra.

Ha elfogadjuk, hogy a beáramló külföldi közvetlen tőke kedvező hatást gyakorol a fogadó ország gazdasági növekedésére, akkor a következő kérdés az, hogy ez a hatás milyen transzmissziós csatornán keresztül érvényesül. Az endogén növekedési modellek (lásd például Romer, 1986 és 1990) alapján az FDI a technológiatranszfer és a technológiadiffúzió révén járulhat hozzá a gazdasági növekedéshez: a fogadó országba érkező tőke fejlett technológiát hoz magával, amely aztán képes elterjedni a gazdaságban, ezáltal növeli a termelékenységet és az erőforrások hatékonyabb felhasználása révén a kibocsátást. E transzmissziós mechanizmus relevanciáját támasztja alá számos empirikus kutatás is: Borensztein et al., 1998; Bitzer \& Kerekes, 2008; Hermes \& Lensink, 2010; Neto \& Veiga, 2013 és Schneider, 2005. Az elképzelés mögött fontos implicit feltevés húzódik meg: a külföldi közvetlentöke-befektetés valóban fejlett technológiát és magas termelékenységet eredményező eljárásokat képes magával hozni. Ez akkor érvényes, ha az az ország, amelyből érkezik, fejlett technológiával rendelkezik, és termelékenységi szintje magas. Ennek a tanulmánynak ez az implicit feltevés áll a középpontjában. Azt vizsgálja, hogy eltérő hatást gyakorol-e a gazdasági növekedésre a magas termelékenységủ és alacsony termelékenységű országokból érkező közvetlentőke-befektetés. A hipotézisem szerint igen. 
Módszertan

A makrogazdasági növekedés és a külföldi közvetlentőke-befektetés közötti hosszú távú kapcsolat meglétét kointegrációs modell segítségével tesztelem. A kointegrációs tesztek azt vizsgálják, hogy különböző nemstacionárius idősorok együtt mozognak-e valamiféle hosszú távú egyensúly körül, vagyis van-e olyan lineáris kombinációjuk, amely stacionáriusnak tekinthető. A hagyományos, úttörő kointegrációs modell Engle és Granger (1987) tanulmányában került felírásra, majd ezt fejlesztette tovább Phillips és Ouliaris (1990), Engle és Yoo (1987), valamint Johansen (1991).

Az említett modelleknek fontos közös tulajdonsága, hogy a vizsgált idősorok elsőrendủ integráltságát (I(1)) feltételezik. Ezért szükség van a modellekben használt idősorok előzetes tesztelésére, ami különböző egységgyöktesztek segítségével végezhető el. A módszertani irodalom ugyanakkor számos kritikát hoz fel e tesztekkel szemben, lásd például Patterson $(2011,2012)$ szintetizáló könyveit. Ha pedig az előzetes tesztek alapján rossz következtetéseket vonunk le az integráltsági rendröl, akkor az alkalmazott kointegrációs modell alapfeltevése sérül, és így a modell eredménye is helytelen.

Ezért ebben az írásban az ún. autoregresszív osztott késleltetésű modellt (autoregressive distributive lag model, a továbbiakban: ARDL) és az arra épülő intervallumhatár-tesztet használom a kointegráció becslésére. Ez a módszertan kevesebb megkötést kíván meg az idősorok integráltságára vonatkozóan, és egyéb elönyei is vannak:

- Az ARDL-technika akkor is alkalmazható, ha a modellben használt változók különböző rendben (I(0), I(1) vagy frakcionálisan) integráltak (Pesaran et al., 2001). Azt ugyanakkor megkívánja a módszer, hogy a maximális integráltsági rend I(1) legyen.

- Kisebb számosságú mintán megbízhatóbb eredményeket ad (Haug, 2002; Pesaran et al., 2001).

- Az ARDL-modell autokorreláció és endogenitás esetén is torzítatlan együtthatókat és valid t-statisztikákat ad (Harris \& Sollis, 2003; Nkoro \& Uko, 2016). Elméleti szempontból a jelen témánál az endogenitás felmerül, azonban az ARDLmodell a megfelelő késleltetésszám alkalmazásával megszünteti a reziduumok autokorrelációját, ezáltal az endogenitási problémát is kezeli.

Az ARDL-modell alapját a sztenderd AR-modell képezi, az előrejelezni kívánt változó adott időszaki értékét azonban nem pusztán annak múltbeli értékével, ha- 
nem egy másik releváns változó értékeivel is magyarázzuk (Pesaran \& Shin, 1999; Pesaran et al., 2001). A $p$ és $q$ késleltetésủ ARDL-modell, ARDL(p,q) az alábbi összefüggéssel adató meg:

$$
y_{t}=c_{0}+c_{1} \cdot t+\sum_{i=1}^{p} \cdot \alpha_{\mathrm{i}} \cdot y_{\mathrm{t}-\mathrm{i}}+\sum_{i=0}^{q} \beta_{i} \cdot x_{t-i}+\varepsilon_{t}
$$

A modell változóinak késleltetési hossza a Bayes-féle információs kritérium (BIC) alapján kerül meghatározásra. Ebben a tanulmányban az (1)-es egyenlet függő változója a reál GDP növekedési rátája (growth), és az alábbi, (2)-es egyenlettel jelölt specifikációt írjuk fel.

growth $_{t}=c_{0}+c_{1} \cdot t+\sum_{i=1}^{p} \alpha_{i} \cdot$ growth $_{t-i}+\sum_{i=0}^{q} \beta_{i} \cdot \ln F D I_{t-i}^{\text {nagyTFP }}+\sum_{i=0}^{r} \gamma_{i} \cdot \ln F D I_{t-i}^{\text {kisTFP }}+\varepsilon_{t}$

Itt a magyarázó változó a növekedési ráta késleltetett értékei, valamint a termelékenyebb országból és a kevésbé termelékeny országból érkező FDI természetes alapú logaritmusa. Pesaran et al. (2001) alapján az (1)-es egyenlet hibakorrekciós alakjából [lásd (3)-as egyenlet] tesztelhetjük a hosszú távú kapcsolat, a kointegráció meglétét az ún. intervallumhatár-teszt segítségével.

$$
\Delta y_{t}=c_{0}+c_{1} \cdot t-\alpha \cdot y_{t-1}+\theta \cdot x_{t-1}+\sum_{i=1}^{p-1} \varphi_{i} \cdot \Delta y_{t-i}+\Sigma_{i=0}^{q-1} \omega_{i} \cdot \Delta x_{t-i}+u_{t}
$$

A kointegráció hiányának nullhipotézisét F-teszt és t-teszt segítségével teszteljük. A hipotézis formalizálása a következö:

$\mathrm{H}_{0}: \alpha=\theta=0$, azaz nincs hosszú távú kapcsolat.

$\mathrm{H}_{1}: \alpha \neq 0$ vagy $\theta \neq 0$, azaz van hosszú távú kapcsolat.

A teszteléshez szükséges kritikus értékeket Kripfganz és Schneider (2021) közli. ${ }^{2}$ Ha mind az F-, mind a t-statisztikák közelebb vannak a 0 -hoz, mint az I(0) változóhoz tartozó kritikus értékek, akkor a kointegráció hiányának nullhipotézise nem utasítható el. Ha mind az F-, mind a t-statisztikák távolabb vannak a 0-tól, mint az I(1) változóhoz tartozó kritikus értékek, akkor a kointegráció hiányának nullhipotézise elutasítható. Egyéb esetekben a teszt inkonkluzív. A Stata szoftver p-értékeket is közöl, amelyek szintén segítik a döntést.

${ }^{2}$ Kripfganz és Schneider (2021) rámutatott, hogy a Pesaran és szerzőtársai (2001) által meghatározott kritikus értékek kis minták esetén nem megbízhatóak, így a tanulmányban az alacsony mintaelemszám miatt a Kripfganz és Schneider (2021) által javasolt kritikus értékeket használom. A megbízhatóság növelése érdekében a Turner (2006) által javasolt kritikus értékek mellett is tesztelem a kointegráció hiányának nullhipotézisét. 
A használt idősorok integráltsági rendjét a széles körben használt Augmented Dickey-Fuller, ADF (Fuller, 1976) és Phillips-Perron, PP (Phillips \& Perron, 1988) tesztekkel ellenőriztem. Fontos ugyanakkor megjegyezni, hogy a vizsgált időszak magába foglalja a 2008-2009. évi világgazdasági válságot is, ami strukturális törést okozhat az idősorokban. Ebben az esetben a standard egységgyöktesztek megbízhatósága jelentősen romlik. Ezért az ADF- és PP-tesztek mellett az integráltságot a Zivot-Andrews-teszt, ZA (Zivot \& Andrews, 1992) segítségével is ellenőriztem, amely endogén módon kezeli a strukturális törést. Mindhárom teszt nullhipotézise az egységgyökfolyamat.

Az intervallumhatár-teszt validitásának feltétele Kripfganz és Schneider (2018) alapján, hogy a reziduumok normális eloszlást követnek, homoszkedasztikusak és nem autokorreláltak, a becsült együtthatók pedig időben stabilak. E feltételek teljesülését különböző formális tesztek segítségével vizsgáltam, amelyek részleteit az alábbiakban közlöm.

A reziduumok normalitását a Shapiro-Wilk-féle W-teszt (lásd: Shapiro \& Wilk, 1965 és Royston, 1992a) segítségével, valamint egy csúcsossági és ferdeségi tesztek kombinálásaként elő́lló próbát használva ellenőriztem, amelynek részletes leírása D’Agostino és munkatársai (1990), valamint Royston (1992b) tanulmányaiban olvasható. Mindkét teszt az alábbi null- és alternatív hipotézist vizsgálja:

$\mathrm{H}_{0}$ : Normális eloszlású reziduumok.

$\mathrm{H}_{1}$ : Nemnormális eloszlású reziduumok.

A homoszkedaszticitást a Breusch-Pagan-féle teszt (lásd Breusch \& Pagan, 1979) és a White-teszt (lásd White, 1980) segítségével vizsgálom. Mindkét teszt az alábbi null- és alternatív hipotézist vizsgálja:

$\mathrm{H}_{0}$ : Homoszkedasztikus reziduumok.

$\mathrm{H}_{1}$ : Heteroszkedasztikus reziduumok.

Az autokorreláltságot két teszt segítségével tesztelem, az alternatív Durbin-teszt (Durbin, 1970), valamint a Breusch-Godfrey-féle LM-teszt (Godfrey, 1978) segítségével. ${ }^{3} \mathrm{~A}$ tanulmányban használt alacsony mintaelemszám miatt mindkét teszt kalkulációjakor alkalmazom a Davidson és MacKinnon (1993) által javasolt kismintás korrekciót. Mindkét teszt az alábbi null- és alternatív hipotézist vizsgálja:

${ }^{3}$ Wooldridge (2008) felhívta a figyelmet arra, hogy ha a függő változó késleltetettje is szerepel a modellben, akkor a sztenderd Durbin-Watson-féle teszt hibás eredményt ad, és helyette az alternatív Durbin-tesztet javasolta. Nem követeli meg a magyarázó változók szigorú exogenitását a BreuschGodfrey-féle LM-teszt sem, amely magasabb rendủ autokorreláció meglétének tesztelésére is alkalmas. 
$\mathrm{H}_{0}$ : Nincs autokorreláció a modellben.

$\mathrm{H}_{1}$ : Van autokorreláció a modellben.

A becsült együtthatók időbeli stabilitását Brown és szerzőtársai (1975) által javasolt CUSUM- és CUSUMSQ-tesztek segítségével tesztelem. A tesztek grafikus reprezentációjában, ha a rekurzív módon számolt tesztstatisztikák végig az 5 százalékos kritikus határon belül maradnak, az együtthatók stabilitására vonatkozó nullhipotézis nem utasítható vissza. Ebben az esetben a hibakorrekciós modellben becsült együtthatók stabilnak tekinthetők, a modell pedig robusztus.

Végül pedig alkalmaztam a Ramsey-féle RESET-tesztet (Ramsey, 1969) is, amely a modell specifikációs hibáját vizsgálja, így egyfajta általános tesztként szolgál. A teszt az alábbi null- és alternatív hipotézist vizsgálja:

$\mathrm{H}_{0}$ : Helyes modellspecifikáció.

$\mathrm{H}_{1}$ : Hibás modellspecifikáció.

Összefoglalva tehát az ARDL-módszertan lényegét, az elemzés során az alábbi lépéseket követem:

1. lépés: a függő és független változók integráltsági rendjének ellenőrzése.

2. lépés: az ARDL hibakorrekciós alakjának felírásának becslése.

3. lépés: az intervallumhatár-teszt végrehajtása.

4. lépés: a hosszú távú együtthatók értelmezése.

5. lépés: modelldiagnosztikai tesztek végrehajtása.

\section{Adatok}

Az elemzés során a 2001 és 2018 közötti időszakot vizsgáltam (tehát a mintaelemszám $18^{4}$ ), és három idősort használtam fel, amelyek a következők: GDP növekedési ráta, országszintű teljes tényezőtermelékenység (TFP) és beáramló külföldi közvetlen tőke. Alább a felhasznált idősorokat részletesebben bemutatom.

${ }^{4}$ Az adatok elérhetősége miatt ugyan nem igazán jellemző az ilyen alacsony mintaelemszám az ARDL-modell és az intervallumhatár-teszt alkalmazásakor, mégis találunk rá példákat. Oudat és munkatársai (2019) Jordániában vizsgálták az FDI növekedésre gyakorolt hatását 1992 és 2013 között, míg Soylu (2019) egy 24 évből álló idősoron elemezte a kérdést lengyel adatokon. Akbota és Baek (2018) egy 1991 és 2014 közötti idősort használva alkalmazta az ARDL-modellt a növekedés $\mathrm{CO}_{2}$ kibocsátásra gyakorolt hatását vizsgálva Kazahsztánban. Tang és Abosedra (2014) Libanon 16 évnyi adatát használva elemezte a turizmusvezérelt-növekedés hipotézisét. Mano-Bakalinov (2016) a kereskedelmi liberalizáció növekedésre gyakorolt hatását vizsgálta 21 évnyi macedón adaton. Tang és Nair (2002) a maláj importkeresleti függvényt becsülte egy 18 év hosszú idősoron, Mah (2000) pedig a koreai importkeresletet vizsgálta 1980 és 1997 közötti idősoron. 
A futtatott modellek függő változója Magyarország konstans áras bruttó hazai termékének százalékos változása, azaz a növekedési ráta (growth). A GDP-adatok a Világbank honlapjáról származó konstans áron számolt bruttó hazai termék értékek, forintban kifejezve. A növekedési ráta kiszámítása az alábbi, sztenderd képlet alapján történt:

$$
\text { growth }=\frac{G D P_{t}-G D P_{t-1}}{G D P_{t-1}} \cdot 100
$$

A 2. táblázat az így kiszámolt növekedési ráta főbb leíró statisztikáit mutatja.

\section{A változatlan áras GDP növekedési ütemét leíró adatok}

\begin{tabular}{c|c|c|c|c}
\multicolumn{5}{c}{ (Százalék) } \\
\hline Átlag & Szórás* & Minimum & Maximum & Medián \\
\hline 2,402 & 2,942 & $-6,700$ & 5,094 & 3,938 \\
\hline
\end{tabular}

Megjegyzések: * százalékpont.

Forrás: Saját számítások a Világbank adatai alapján.

Teljes tényezötermelékenység

Ennek a résznek a célja, hogy megmutassa, makrogazdasági hatását tekintve számít-e, hogy honnan érkezik Magyarországra a külföldi közvetlentőke-befektetés. A hipotézisem szerint az FDI a technológiai csatornán keresztül fejti ki jótékony hatását a gazdasági növekedésre, azaz az várható, hogy a termelékenyebb országokból érkező közvetlen tőkének van igazán szignifikáns pozitív hatása a növekedési rátára. A hipotézis tesztelése érdekében a Magyarországra irányuló külföldi közvetlentőke-befektetéseket két csoportba sorolom. Az első csoportot az az FDI alkotja, amely Magyarországnál termelékenyebb országból érkezik, a másodikat pedig az az FDI, amely kevésbé termelékeny országból áramlik be. ${ }^{5}$ Ennek alapján az adatokat

${ }^{5}$ Az elemzett mintában hatvan ország szerepel: a vizsgált időszakban összesen hatvanhat országból érkezett FDI Magyarországra. (1) Fehéroroszország, a Brit Virgin-szigetek, Liechtenstein, Montenegró, Macedónia és Tajvan kiesik az elemzésből, mert nem érhető el termelékenységi adat. (2) Harmincnégy olyan ország van a mintában, ahol a teljes megfigyelési periódus alatt Magyarországé- 
a küldő ország termelékenysége szerint két csoportba aggregáltam. A két csoport közötti megkülönböztetés alapját a Penn World Table 9.1 adatbázis teljes tényezőtermelékenységi mutatója (ctfp) adja. A mutató számításának módszertanáról részletes leírást ad Feenstra et al. (2015). A végső elemzési mintában 44 termelékenyebb és 16 kevésbé termelékeny ország található.

Külföldi közvetlentöke-befektetés

A külföldi közvetlentőke-befektetésekre vonatkozó adatokat a Magyar Nemzeti Bank (MNB) honlapjáról töltöttem le. Az MNB többfajta FDI-idősort publikál, ebben az írásban a teljes, azaz a részvény- és egyéb részesedéseket, újrabefektetett jövedelmeket, valamint az adósság típusú instrumentumokat is tartalmazó, forgalmi szemléletű, speciális célú vállalatok (SCV-k) nélküli, átfolyó tőkétől és eszközportfólió-átrendezéstől tisztított adatok kerülnek felhasználásra. Az idősor eredeti mértékegysége millió forint. ${ }^{6}$

A letöltött FDI-idősort a Központi Statisztikai Hivatal által publikált beruházásiár-index segítségével alakítottam konstans áras adattá. A 2. táblázat a regressziós modellekben használt, beáramló reálosított külföldi közvetlentöke-befektetések föbb leíró statisztikáit tartalmazza.

A beáramló külföldi közvetlentőke-befektetés jelentős ingadozást mutatott, ami egybecseng az üzleti ciklusok szakirodalmában megállapítottakkal, lásd például Tőkés, 2019a. Az elemzési időszakban éves átlagban 167 milliárd forintnyi közvetlen

nál nagyobb volt a teljes tényezőtermelékenység. Ezek a következők: Ausztrália, Ausztria, Belgium, Bulgária, Ciprus, Dánia, Egyesült Királyság, Egyiptom, Finnország, Franciaország, Hongkong, Hollandia, Horvátország, Izland, Izrael, Írország, Japán, Kanada, Lengyelország, Litvánia, Luxemburg, Málta, Mexikó, Németország, Norvégia, Olaszország, Portugália, Spanyolország, Svájc, Svédország, Szlovénia, Törökország, USA és Új-Zéland. (3) Nyolc olyan ország van, amelyre a teljes megfigyelési időszakban a magyarnál alacsonyabb termelékenység volt jellemző. Ezek a következők: Brazília, Fülöp-szigetek, India, Indonézia, Kína, Szerbia, Tajföld és Ukrajna. (4) Tizennyolc országra vegyes trendek voltak jellemzök. Egyes években a termelékenység meghaladta a magyarországit, más években elmaradt attól. Ezeket is besoroltam az előző két kategóriába annak alapján, hogy melyik eset a gyakoribb. Így a következő országok kerültek a termelékenyebb csoportba (zárójelben az évek száma, amelyekben termelékenyebbek, illetve kevésbé termelékenyek voltak): Argentína (15-2), Chile (12-5), Dél-afrikai Köztársaság (11-6), Görögország (10-7), Irán (14-3), Korea (13-4), Románia (13-4), Szingapúr (16-1), Szlovákia (15-2) és Uruguay (12-5). A következő országok pedig a kevésbé termelékeny csoportba kerültek (zárójelben az évek száma, amelyekben termelékenyebbek, illetve kevésbé termelékenyek voltak): Csehország (2-15), Észtország (4-13), Kolumbia (4-13), Lettország (2-15), Malajzia (8-9), Marokkó (1-16), Oroszország (3-14) és Venezuela (4-13).

${ }^{6}$ Az FDI-idősor küldő ország szerinti bontása a 2001 és 2018 közötti időszakra érhető el. A tanulmányban használt adatok közül ez a szủk keresztmetszet, ez definiálja a vizsgált időszakot, így a 2001 és 2018 közötti időszakot elemeztem. 
tőke érkezett be Magyarországra 1990. évi árakon számolva. Ez jelentős, 73 milliárd forintnyi szórást mutatott, és a 61 milliárd forint és 298 milliárd forint közötti sávban mozgott, miként az a 3. táblázatból kivehető.

3. táblázat

\section{A külföldi közvetlentőke-befektetések főbb jellemzői}

(Milliárd forint 1990. évi árakon)

\begin{tabular}{l|c|c|c|c|c}
\hline Statisztika & Átlag & Szórás & Minimum & Maximum & Medián \\
\hline FDI & 167,387 & 73,129 & 61,756 & 297,942 & 167,326 \\
\hline
\end{tabular}

Megjegyzés: Forgalmi szemléletű, speciális célú vállalatok nélküli, átfolyó tőkétől és eszközportfólióátrendezéstől tisztított, beruházásiár-index segítségével reálosított adatok.

Forrás: Saját számítás a Magyar Nemzeti Bank adatai alapján.

Az ARDL-modellekben a külföldi közvetlentőke-forgalom természetes alapú logaritmusát szerepeltettem. Ez bizonyos esetekben matematikai problémát okoz, ugyanis egyes években a küldő ország termelékenysége alapján aggregált adatokban előfordul negatív érték, amelynek a természetes alapú logaritmusa nem képezhető meg. Ezért a logaritmusképzésnél követtem az irodalomban bevett szokást, 7 azaz az adott érték abszolút értékének vettem a természetes alapú logaritmusát, majd azt elláttam az eredeti érték előjelével. Az eljárást az alábbi, (5) egyenlet foglalja össze:

$$
\operatorname{lnFDI}=\operatorname{elöjel}(F D I) \cdot \ln (|F D I|)
$$

A 2. ábra a három vizsgált idősor időbeli alakulását mutatja: a GDP százalékos növekedési rátáját, valamint az alacsony és magas termelékenységủ országokból érkező tőke természetes alapú logaritmusát.

7 Az elterjedt megoldás esetében valójában az (1 + FDI) abszolút értékét veszik (a nullás értékek kezelése érdekében, ami bilaterális FDI-adatok esetén gyakran előfordul), de mivel ebben a tanulmányban nullás FDI-értékek nincsenek, így ez a megoldás sem szükséges. A módszer alkalmazását lásd például Eichengreen és Irwin (1995), Yeyati és munkatársai (2007) vagy Tökés (2019a) írásaiban. 


\section{A vizsgált idősorok időbeli alakulása}

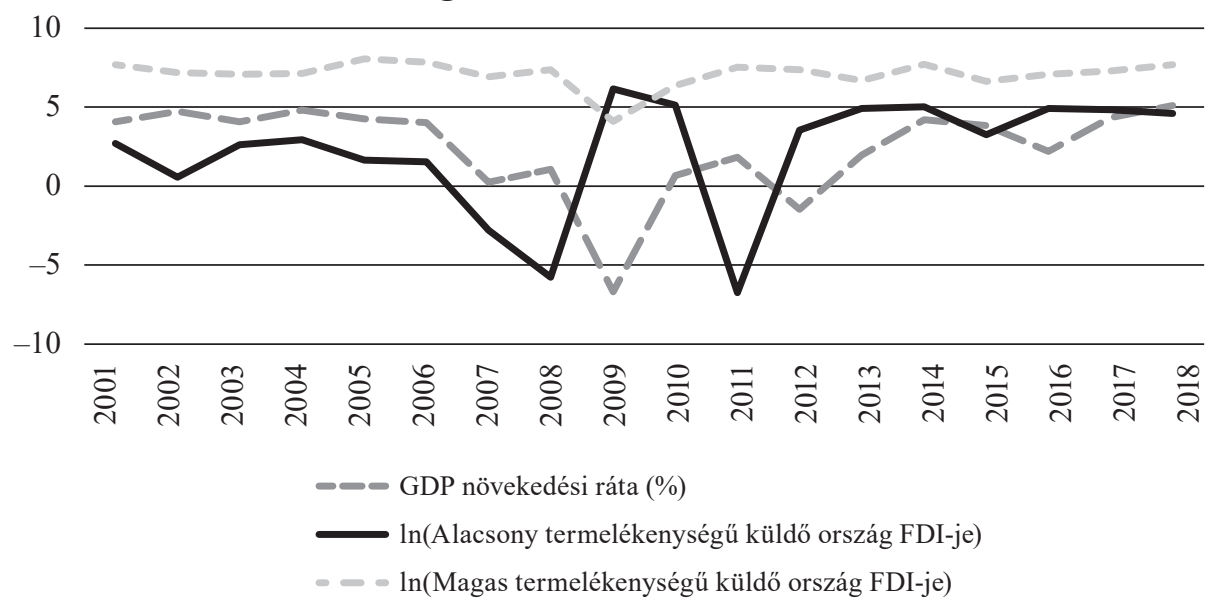

Forrás: Saját szerkesztés a Világbank és a Magyar Nemzeti Bank adatai alapján.

\section{Eredmények}

Az elöző részben ismertetett lépéseket követve az eredmények az alábbiak. Az egységgyöktesztek eredményeit a 4. táblázat mutatja. Ennek alapján az alacsony, illetve magas termelékenységü küldő országokból érkező FDI-idősorok is I(0) folyamatnak tekinthetők, azaz az ARDL-modell becsülhetö.

A magyarázó változókra vonatkozó egységgyöktesztek

\begin{tabular}{l|c|c|c|c|c|c}
\hline \multirow{2}{*}{ Változó } & \multicolumn{2}{|c|}{ Aug. Dickey-Fuller } & Phillips-Perron & \multicolumn{2}{c}{ Zivot-Andrews } \\
\cline { 2 - 7 } & Szint & Döntés & Szint & Döntés & Szint & Döntés \\
\hline $\begin{array}{l}\text { Alacsony termelékenységü } \\
\text { küldő ország FDI-je }\end{array}$ & $-3,60^{\mathrm{a}}$ & $\mathrm{I}(0)$ & $-3,56^{\mathrm{a}}$ & $\mathrm{I}(0)$ & $-6,67^{\mathrm{a}}$ & $\mathrm{I}(0)$ \\
$\begin{array}{l}\text { Magas termelékenységű küldő } \\
\text { ország FDI-je }\end{array}$ & $-3,51^{\mathrm{a}}$ & $\mathrm{I}(0)$ & $-3,50$ & $\mathrm{I}(0)$ & $-4,83^{\mathrm{b}}$ & $\mathrm{I}(0)$ \\
\hline
\end{tabular}

Megjegyzés: A táblázatban szereplő számok a tesztstatisztika értékei. a,b,c rendre az 1, 5 és 10 százalékos szignifikanciaszintet jelzik.

Forrás: Saját számítások az MNB, a KSH, a PWT és a Világbank adatai alapján. 
Az integráltsági rend ellenőrzése után megbecsültem az ARDL-modell hibakorrekciós formáját, és végrehajtottam az intervallumhatár-tesztet. Ennek eredményét a 4. táblázat mutatja. A legjobb illeszkedést az ARDL(2,1,0)-modell mutatta, mind a Bayes, mind az Akaike információs kritériumok alapján.

5. táblázat

Az ARDL-modellre vonatkozó intervallumhatár-teszt

\begin{tabular}{l|c|c|c|c|c|c|c|c}
\hline \multicolumn{3}{c|}{ Tesztstatisztikák értékei: } & \multicolumn{2}{c|}{$\mathrm{F}=18,67$} & \multicolumn{2}{c}{$\mathrm{t}=-4,94$} \\
\hline \multirow{2}{*}{$\begin{array}{l}\text { Kritikus } \\
\text { értékek }\end{array}$} & \multicolumn{2}{c|}{$10 \%$} & \multicolumn{2}{c|}{$5 \%$} & \multicolumn{2}{c}{$1 \%$} & \multicolumn{2}{c}{$\mathrm{p}$-érték } \\
\cline { 2 - 9 } & $\mathrm{I}(0)$ & $\mathrm{I}(1)$ & $\mathrm{I}(0)$ & $\mathrm{I}(1)$ & $\mathrm{I}(0)$ & $\mathrm{I}(1)$ & $\mathrm{I}(0)$ & $\mathrm{I}(1)$ \\
\hline $\mathrm{F}$ & 3,84 & 5,17 & 5,06 & 6,69 & 8,59 & 11,02 & 0,001 & 0,001 \\
$\mathrm{t}$ & $-2,62$ & $-3,30$ & $-3,07$ & $-3,82$ & $-4,09$ & $-4,99$ & 0,003 & 0,011 \\
\hline
\end{tabular}

Forrás: Saját számítások az MNB, a KSH, a PWT és a Világbank adatai alapján.

Az 5. táblázatban látható eredmények alapján a kointegráció hiányának nullhipotézise 5 százalékos szignifikanciaszint mellett elvethető, azaz az idősorokat tekinthetjük kointegráltnak. ${ }^{8}$ A becsült modell hosszú távú együtthatóját az alábbi, 6. táblázat mutatja.

6. táblázat

Az ARDL-modell becsült hosszú távú együtthatója

\begin{tabular}{l|c|c|c}
\hline Változó & Együttható & Standard hiba & p-érték \\
\hline Alacsony termelékenységű küldő ország FDI-je & 0,008 & 0,002 & 0,007 \\
Magas termelékenységü küldő ország FDI-je & 0,028 & 0,007 & 0,002 \\
\hline \multicolumn{2}{|c}{ korr. R ${ }^{2}=0,888$} \\
\hline
\end{tabular}

Forrás: Saját számítások az MNB, a KSH, a PWT és a Világbank adatai alapján.

Miként az a 6. táblázatban látható, mindkét FDI-együttható minden szokásos szignifikanciaszinten szignifikáns és pozitív: a beáramló külföldi közvetlen tőke pozitív hatást gyakorol a GDP növekedési rátájára, függetlenül attól, hogy melyik

8 A kointegráció hiányának nullhipotézise a Kripfganz \& Schneider (2021), illetve a Turner (2006) által javasolt kritikus értékek (lásd 2-es lábjegyzet) mellett is elvethető. 
országcsoportból érkezik. Vegyük azonban észre, hogy az együtthatók nagysága között jelentős különbség van. A magasabb termelékenységü küldő országból érkező FDI hatása erősebb. Ha a beáramló FDI 1 százalékkal növekszik, akkor az a reál GDP növekedési rátáját 0,00008 százalékponttal emeli, ha a tőke Magyarországnál alacsonyabb termelékenységű országból érkezik, és 0,0028 százalékponttal, ha magasabb termelékenységü országból származik.

Végül a modell validitását ellenőrizendő, lefuttattam a modelldiagnosztikai teszteket, amelyek eredményét a 7. táblázat tartalmazza.

7. táblázat

Az ARDL-modell modelldiagnosztikai tesztjei

\begin{tabular}{lcccl}
\hline Teszt & $\begin{array}{c}\text { Tesztsta- } \\
\text { tisztika }\end{array}$ & p-érték & Eredmény \\
\hline Alternatív Durbin-teszt & 0,19 & 0,664 & Nincs autokorreláció \\
Breusch-Godfrey-féle LM teszt & 0,33 & 0,566 & Nincs autokorreláció \\
Breusch-Pagan-féle teszt & 1,09 & 0,297 & Homoszkedaszticitás \\
White-teszt & 16,00 & 0,382 & Homoszkedaszticitás \\
Alakmutatókon alapuló normalitási teszt & 0,24 & 0,889 & Normális eloszlású reziduumok \\
Shapiro-Wilk-féle W-teszt & 0,97 & 0,855 & Normális eloszlású reziduumok \\
Ramsey-féle RESET teszt & 0,23 & 0,874 & Nincs kihagyott változó \\
\hline
\end{tabular}

Forrás: Saját számítások az MNB, a KSH, a PWT és a Világbank adatai alapján.

Látható, hogy a reziduumok autokorrelálatlanságára vonatkozó alternatív Durbin-teszt és Breusch-Godfrey-féle LM-teszt alapján az autokorreláció hiányának nullhipotézise nem vethető el. A Breusch-Pagan-féle teszt és a White-teszt alapján a reziduumokra vonatkozó homoszkedaszticitási nullhipotézis sem vethető el. A hibatagok normalitására vonatkozó nullhipotézis a csúcsossági és ferdeségi mutatókon alapuló normalitási teszt és a Shapiro-Wilk-féle W-teszt alapján sem vethető el. A Ramsey-féle RESET teszt alapján a modellspecifikáció is helyesnek tekinthető.

Miként az a 3. ábrán látható, a CUSUM- és CUSUMSQ-adatok az 5 százalékos kritikus határon belül mozognak, azaz a modell paraméterei stabilnak tekinthetőek. 


\section{A CUSUM- és CUSUMSQ-eredmények}

Alacsony termelékenységü küldő ország CUSUM

- - 5\%-os kritikus határ

Alacsony termelékenységü küldő ország CUSUMQ

- - 5\%-os kritikus határ

Magas termelékenységü küldő ország CUSUM

- - 5\%-os kritikus határ

Magas termelékenységủ küldő ország CUSUMQ

- . 5\%-os kritikus határ
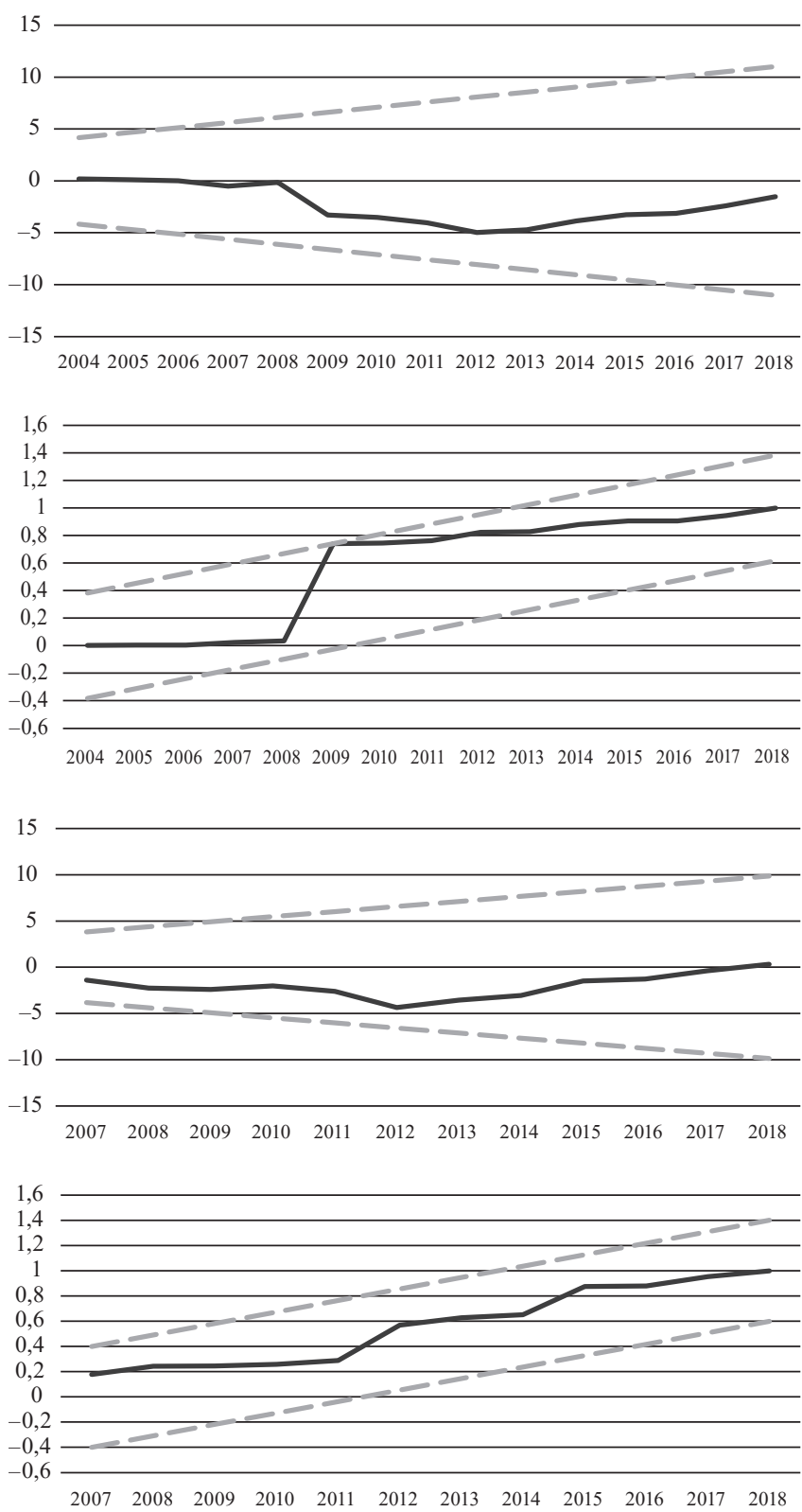

Forrás: Saját számítás az MNB, a KSH, a PWT és a Világbank adatai alapján. 
Összefoglalásként megállapítható, hogy az illesztett ARDL-modell alapján a Magyarországra áramló külföldi közvetlen tőke statisztikailag szignifikáns és pozitív hatást gyakorolt a reál GDP növekedési rátájára, függetlenül attól, hogy alacsony vagy magas termelékenységű országból érkezett. A magas termelékenységủ országból érkezett közvetlentőke-befektetés növekedésre gyakorolt hatása lényegesen nagyobb, az alacsonyabb teljes tényezőtermelékenységgel jellemezhető küldő országból érkező közvetlentőke-befektetés hatásának több mint háromszorosa. Ez a hatásbeli különbség értelmezhető a korábban bemutatott technológiatranszfercsatorna bizonyítékaként. A termelékeny országok részben a magas technológiai fejlettség miatt termelékenyebbek, így a kevésbé termelékeny országokhoz képest fejlettebb technológiával rendelkeznek, és ezt a fejlettebb technológiát viszik magukkal a fogadó országba. A fogadó országban pedig ez a fejlettebb technológia az irodalomáttekintésben bemutatott közvetlen és közvetett módon növeli a termelékenységet - mégpedig a kevésbé termelékeny országból érkező tőkéhez képest nagyobb mértékben -, és így a gazdasági növekedésre gyakorolt hatása is erősebb, mint a kevésbé termelékeny küldő országok esetén. Az eredmények alapján megfogalmazható elméleti következtetés tehát, hogy az FDI hatása heterogén, annak homogén masszaként történő kezelése nem adekvát, a technológiatranszfer miatt a termelékenyebb országokból érkező külföldi közvetlentőke-befektetés gazdasági növekedésre gyakorolt hatása erősebb, az intenzív növekedéshez való hozzájárulása nagyobb, mint a kevésbé termelékeny küldő országból érkező tőkéé. Ez az eredmény összhangban van az endogén növekedéselméleti modellek implikációival is.

\section{Összefoglalás és következtetések}

Az 1989. évi rendszerváltás után Magyarország is a külföldi közvetlentőke-befektetések kedvelt célállomása lett. A külföldi közvetlentőke-befektetés makrogazdaságra gyakorolt hatásával nagyszámú szakirodalmi forrás foglalkozik. Többségük arra az eredményre jutott, hogy a külföldi közvetlentőke-befektetés jótékonyan hat a gazdasági növekedésre, ennek fő transzmissziós mechanizmusa pedig a technológiatranszfer. A külföldi tőke fejlett technológiát is visz magával a fogadó országba, ami közvetlenül és a tovagyürüző hatások révén közvetve is javítja a makroszintü termelékenységet, ezáltal serkenti a gazdasági növekedést. A tanulmány a 2001 és 2018 között Magyarországra érkezett FDI reál GDP növekedési rátára gyakorolt hatását vizsgálta az ún. autoregresszív osztott késleltetésủ modell segítségével. Ha a 
fö transzmissziós mechanizmus valóban a technológiatranszfer, a termelékenység növekedése, akkor várható, hogy a fejlett technológiát hozó FDI nagyobb mértékben emeli a GDP-dinamikát. Ezért a Magyarországra beáramló FDI-idősort két csoportba soroltam: (i) Magyarországnál magasabb termelékenységű országokból érkező közvetlentőke-befektetés, valamint (ii) Magyarországnál kevésbé termelékeny államokból származó tőke. Az így felírt modell eredményei megerősítették a felállított nullhipotézist: a termelékenyebb országokból érkező FDI növekedési rátára gyakorolt hatása körülbelül háromszor akkora, mint a kevésbé termelékeny országokból érkező tőkéé. Az eredményeknek két tanulsága is van: az egyik tudományos szempontból, a másik pedig szakpolitikai szempontból releváns. Egyrészt rávilágít arra, hogy a tudományos kutatásokban a külföldi közvetlen tőkét nem szabad homogén masszaként kezelni, mert annak hatásai eltérőek lehetnek.

Másrészt mindez a befektetésösztönző politikával foglalkozó döntéshozók számára is iránymutató lehet.

A tanulmány eredményei alapján a külföldi közvetlentőke-befektetések vonzását ösztönző politikákat érdemes lehet szelektív módon alakítani, és célzottan a fejlett, termelékeny küldő országokból származó befektetéseket támogatni, mert annak gazdasági növekedésre gyakorolt hatása nagyobb. A kutatás eredményei alapján látható, hogy a termelékeny országból érkező FDI növekedésserkentő hatása jelentösebb, így a célzott ösztönzési politika - értsd: a fejlettebb FDI vonzására tett kísérletek - jobban megtérülhet. Egyrészt a fejlett országokból származó FDI nagyobb mértekben járul hozzá a gazdasági növekedéshez, másrészt pedig ez a gyorsabb növekedés lehetővé teszi a bérek emelését és a fogyasztás növekedését. Ezáltal a kormányzat magasabb adóbevételekre számíthat, vagyis költségvetési szempontból is előnyösebb, mert a külföldi közvetlen tőkének nyújtott támogatások, az ösztönzésre költött erőforrások jobban megtérülhetnek. Érdemes azonban ezeket a következtetéseket az elemzés korlátai miatt fenntartásokkal kezelni.

Fontos ugyanakkor megemlíteni a tanulmány néhány korlátját is, amelyek árnyalják a kapott eredményeket és az azok alapján megfogalmazható szakpolitikai implikációkat is. Az első és legfontosabb korlát adattartalmi jellegü: az FDI-idősorok a közvetlen befektető szerinti csoportosítás alapján kerültek összeállításra, ugyanakkor adekvátabb megoldás lenne a végső befektetô9 szerinti bontást alkalmazni. Sass és munkatársai (2019) több példát is említenek, amikor ázsiai befektetők európai

9 Végső befektetőnek tekintjük „,...) a vállalatcsoport tulajdonosi láncának csúcsán lévő többségi - az adott vállalkozásban közvetve vagy közvetlenül $50 \%$ feletti szavazati joggal rendelkezö - befektetőt, amely fölött más befektető nem gyakorol ellenőrzést (...)" (MNB, 2016:1). 
közvetítő országokon keresztül érkeznek, például indiai vállalatok Hollandián keresztül vagy kínai vállalatok különböző európai országokon keresztül. Ezek a tények pedig torzítást vihetnek a bemutatott becslésekbe, ha a közvetlen és végső befektető szerinti besorolás eltér. Márpedig vannak tendenciózus különbségek, például 2018ban az ázsiai FDI-pozíció GDP-arányosan 2,7 százalék a közvetlen befektető szerinti besorolás alapján, és 10,4 százalék a végső befektető szerinti besorolás alapján. Ugyanakkor ez jelenleg egy erős adatkorlát, a Magyar Nemzeti Bank csupán 2014-ig visszamenően publikálja a végső befektető szerinti bontást, így az adatsor idősoros elemzésre csak igen korlátozottan alkalmazható. A közvetlen befektető szerinti adatok használata tehát árnyalja az eredményeket. A végső befektető szerinti adatok használata fontos jövőbeli kutatási lehetőséget jelent.

Szintén releváns jövőbeli kutatási irány a hatásmechanizmusok pontos feltérképezése, ám erre a makroszintủ adatok helyett inkább a vállalati vagy iparági szintű adatokra való támaszkodás adekvát megközelítés. Ilyen jellegủ kísérletek már vannak (lásd például Tőkés, 2019b).

Érdemes végül e tanulmány korlátjaként megemlíteni azt is - ami a gazdaságpolitikai ajánlásokkal kapcsolatban szintén óvatosságra int -, hogy a kutatás pusztán a gazdasági növekedésre fókuszált, az FDI más területekre (például bérek, hazai beruházások, verseny stb.) gyakorolt hatásával nem foglalkozott. Így a korábban megfogalmazott gazdaságpolitikai implikációk fenntartásokkal kezelendők.

\section{Hivatkozások}

Adams, S., Klobodu, E. K. M., \& Lamptey, R. O. (2017). The effects of capital flows on economic growth in Senegal. Margin: The Journal of Applied Economic Research, 11(2), 121-142. https:// doi.org/10.1177\%2F0973801016687869

Akbota, A. \& Baek, J. (2018). The environmental consequences of growth: empirical evidence from the Republic of Kazakhstan. Economies, 6(1), 1-11. https://doi.org/10.3390/economies6010019

Alfaro, L., Chanda, A., \& Kalemli-Ozcan, S. (2004). FDI and economic growth: the role of local financial markets. Journal of International Economics, 64(1), 89-112. https://doi.org/10.1016/ S0022-1996(03)00081-3

Alvarado, R., Iñiguez, M., \& Ponce, P. (2017). Foreign direct investment and economic growth in Latin America. Economic Analysis and Policy, 56, 176-187. https://doi.org/10.1016/j.eap.2017.09.006

Antalóczy, K. \& Sass, M. (2000). Müködőtőke-áramlások, befektetői motivációk és befektetésösztönzés a világgazdaságban és Magyarországon. Közgazdasági Szemle, 47(5), 473-496.

Antalóczy, K. \& Sass, M., (2003). Befektetésösztönzés és Magyarország csatlakozása az Európai Unióhoz. Külgazdaság, 47, 4-29.

Antalóczy, K. \& Sass, M., (2005). A külföldi müködőtőke-befektetések regionális elhelyezkedése és gazdasági hatásai Magyarországon. Közgazdasági Szemle, 52(5), 494-520. 
Azman-Saini, W. N., Baharumshah, A. Z., \& Law, S. H. (2010). Foreign direct investment, economic freedom and economic growth: International evidence. Economic Modelling, 27(5), 1079-1089. https://doi.org/10.1016/j.econmod.2010.04.001

Bačić, K., Račić, D., \& Ahec Šonje, A. (2004). FDI and economic growth in Central and Eastern Europe: Is there a link? (Working Paper No. 83136). Munich Personal RePEc Archive.

Balasubramanyam, V. N., Salisu, M., \& Sapsford, D. (1996). Foreign Direct Investment and Growth in EP and IS Countries. Economic Journal, 106(434), 92-105. https://doi.org/10.2307/2234933

Balatoni, A. \& Pitz, M. (2012). A működő tőke hatása a bruttó nemzeti jövedelemre Magyarországon. Közgazdasági Szemle, 59(1), 1-30.

Baldwin, R., Braconier, H., \& Forslid, R. (2005). Multinationals, endogenous growth, and technological spillovers: Theory and evidence. Review of International Economics, 13(5), 945-963. https://doi. org/10.1111/j.1467-9396.2005.00546.x

Barrell, R. \& Holland, D. (2000). Foreign direct investment and enterprise restructuring in Central Europe. Economics of Transition, 8(2), 477-504. https://doi.org/10.1111/1468-0351.00052

Batten, J. A. \& Vo, X. V. (2009). An analysis of the relationship between foreign direct investment and economic growth. Applied Economics, 41(13), 1621-1641. https://doi. org/10.1080/00036840701493758

Bengoa, M. \& Sanchez-Robles, B. (2003). Foreign direct investment, economic freedom and growth: new evidence from Latin America. European Journal of Political Economy, 19(3), 529-545. https://doi.org/10.1016/s0176-2680(03)00011-9

Bijsterbosch, M. \& Kolasa, M. (2009). FDI and Productivity Convergence in Central and Eastern Europe: An Industry-Level Investigation (ECB Working Paper No. 992). European Central Bank. https://www.ecb.europa.eu/pub/pdf/scpwps/ecbwp992.pdf

Bitzer, J. \& Kerekes, M. (2008). Does foreign direct investment transfer technology across borders? New evidence. Economics Letters, 100(3), 355-358. https://doi.org/10.1016/j.econlet.2008.02.029

Borensztein, E., De Gregorio, J., \& Lee, J-W. (1998). How Does Foreign Direct Investment Affect Economic Growth? Journal of International Economics, 45(1), 115-135. https://doi.org/10.3386/ w5057

Bouchoucha, N. \& Ali, W. (2019). The impact of FDI on economic growth in Tunisia: An estimate by the ARDL approach (MPRA Working Paper No. 91465). Munich Personal RePEc Archive. https:// mpra.ub.uni-muenchen.de/91465/

Bouchoucha, N. \& Sayef, B. (2019). The Impact of Domestic and Foreign Direct Investment on Economic Growth: Fresh Evidence from Tunisia (MPRA Working Paper No. 94777). Munich Personal RePEc Archive. https://mpra.ub.uni-muenchen.de/94777/

Breusch, T. \& Pagan, A. (1979). A Simple Test for Heteroscedasticity and Random Coefficient Variation. Econometrica, 47(5), 1287-1294. https://doi.org/10.2307/1911963

Brown, R. L., Durbin, J., \& Evans, J. M. (1975). Techniques for Testing the Constancy of Regression Relationships over Time. In Source: Journal of the Royal Statistical Society. Series B (Methodological), 37(2): 149-163. https://doi.org/10.1111/j.2517-6161.1975.tb01532.x

Campos, N. F. \& Kinoshita, Y. (2002). Foreign direct investment as technology transferred: Some panel evidence from the transition economies. Manchester School, 70(3), 398-419. https://doi. org/10.1111/1467-9957.00309

Carbonell, J. B. \& Werner, R. A. (2018). Does foreign direct investment generate economic growth? A new empirical approach applied to Spain. Economic Geography, 94(4), 425-456. https://doi.org/1 $0.1080 / 00130095.2017 .1393312$

Choe, J. I. (2003). Do foreign direct investment and gross domestic investment promote economic growth? Review of Development Economics, 7(1), 44-57. https://doi.org/10.1111/1467-9361.00174

Choi, Y. J. \& Baek, J. (2017). Does FDI really matter to economic growth in India? Economies, 5(2), 1-20. https://doi.org/10.3390/economies5020020 
D’Agostino, R. B., Belanger, A., \& D’Agostino, R. B. (1990). A suggestion for using powerful and informative tests of normality. American Statistician, 44(4), 316-321. https://doi.org/10.1080/000 31305.1990 .10475751

Davidson, R. \& MacKinnon, J. G. (1993). Estimation and Inference in Econometrics. Oxford University Press. https://doi.org/10.1017/S0266466600009452

De Gregorio, J. (1992). Economic growth in Latin America. Journal of Development Economics, 39(1), 59-84. https://doi.org/10.1016/0304-3878(92)90057-g

Dhrifi, A. (2015). Foreign direct investment, technological innovation and economic growth: empirical evidence using simultaneous equations model. International Review of Economics, 62(4), 381400. https://doi.org/10.1007/s12232-015-0230-3

Durbin, J. (1970). Testing for Serial Correlation in Least-Squares Regression When Some of the Regressors are Lagged Dependent Variables. Econometrica, 38(3), 410-421. https://doi. org $/ 10.2307 / 1909547$

Durmaz, N. (2017). Foreign direct investments, democracy, and economic growth in Turkey. International Journal of Social Economics, 44(2), 232-252. https://doi.org/10.1108/IJSE-01-20150015

Eichengreen, B. \& Irwin, D. (1995). Trade blocs, currency blocs and the reorientation of world trade in the 1930s. Journal of International Economics, 38(1-2), 1-24. https://doi.org/10.3386/w4445

Engle, R. \& Granger, C. (1987). Co-integration and Error Correction: Representation, Estimation, and Testing. Econometrica, 55(2), 251-276. https://doi.org/10.2307/1913236

Engle, R. \& Yoo, B. S. (1987). Forecasting and testing in co-integrated systems. Journal of Econometrics, 35, 143-159. https://doi.org/10.1016/0304-4076(87)90085-6

Feenstra, R. C., Inklaar, R., \& Timmer, M. P. (2015). The next generation of the Penn World Table. American Economic Review, 105(10), 3150-3182. https://doi.org/10.1257/aer.20130954

Findlay, R. (1978). Relative Backwardness, Direct Foreign Investment, and the Transfer of Technology: A Simple Dynamic Model. Quarterly Journal of Economics, 92(1), 1-16. https://doi. org $/ 10.2307 / 1885996$

Fuller, W. A. (1976). Introduction to Statistical Time Series. John Wiley and Sons.

Gál, Z. (2019). Az FDI szerepe a gazdasági növekedés és a beruházások területi differenciálódásában Magyarországon. Közgazdasági Szemle, 66(6), 653-686. https://doi.org/10.18414/ksz.2019.6.653

Gál, Z., Sass, M., \& Juhász, B. (2016). A külföldi közvetlentőke-befektetések és a válság hatása a fogadó gazdaságra: a visegrádi országok egyes szolgáltató ágazatainak vizsgálata. Külgazdaság, 60(7-8), 51-80.

Gherghina, Ş. C., Simionescu, L. N., \& Hudea, O. S. (2019). Exploring Foreign Direct InvestmentEconomic Growth Nexus-Empirical Evidence from Central and Eastern European countries. Sustainability (Switzerland), 11(19), 5421. https://doi.org/10.3390/su11195421

Godfrey, L. G. (1978). Testing against General Autoregressive and Moving Average Error Models When the Regressors Include Lagged Dependent Variables. Econometrica, 46(6), 1293-1301. https://doi.org/10.2307/1913829

Gui-Diby, S. L. (2014). Impact of foreign direct investments on economic growth in Africa: Evidence from three decades of panel data analyses. Research in Economics, 68(3), 248-256. https://doi. org/10.1016/j.rie.2014.04.003

Gungor, H. \& Ringim, S. H. (2017). Linkage between Foreign Direct Investment, Domestic Investment and Economic Growth: Evidence from Nigeria. International Journal of Economics and Financial Issues, 7(3), 97-104.

Gurgul, H. \& Lach, Ł. (2014). Globalization and economic growth: Evidence from two decades of transition in CEE. Economic Modelling, 36, 99-107. https://doi.org/10.1016/j.econmod.2013.09.022

Harris, R. \& Sollis, R. (2003). Applied Time Series Modelling and Forecasting. John Wiley and Sons. 
Haug, A. A. (2002). Temporal aggregation and the power of cointegration tests: A Monte Carlo study. Oxford Bulletin of Economics and Statistics, 64(4), 399-412. https://doi.org/10.1111/14680084.00025

Hermes, N. \& Lensink, R. (2003). Foreign direct investment, financial development and economic growth. Journal of Development Studies, 40(1), 142-163. https://doi.org/10.1080/002203804123 31293707

Herzer, D. (2012). How Does Foreign Direct Investment Really Affect Developing Countries' Growth? Review of International Economics, 20(2), 396-414. https://doi.org/10.1111/j.14679396.2012.01029.x

Iamsiraroj, S. (2016). The foreign direct investment-economic growth nexus. International Review of Economics and Finance, 42, 116-133. https://doi.org/10.1016/j.iref.2015.10.044

Iamsiraroj, S. \& Ulubaşoğlu, M. A. (2015). Foreign direct investment and economic growth: A real relationship or wishful thinking? Economic Modelling, 51, 200-213. https://doi.org/10.1016/j. econmod.2015.08.009

Johansen, S. (1991). Estimation and Hypothesis Testing of Cointegration Vectors in Gaussian Vector Autoregressive Models. Econometrica, 59(6), 1551-1580. https://doi.org/10.2307/2938278

Koizumi, T. \& Kopecky, K. J. (1977). Economic growth, capital movements and the international transfer of technical knowledge. Journal of International Economics, 7(1), 45-65. https://doi. org/10.1016/0022-1996(77)90004-6

Kornecki, L. (2008). Foreign direct investment and macroeconomic changes in CEE integrating into the global market. Investment Management and Financial Innovation, 5(4), 124-132.

Kripfganz, S. \& Schneider, D. C. (2018). ARDL: Estimating autoregressive distributed lag and equilibrium correction models. London Stata Conference 2018.

Kripfganz, S. \& Schneider, D. C. (2021). Response Surface Regressions for Critical Value Bounds and Approximate p-values in Equilibrium Correction Models. Oxford Bulletin of Economics and Statistics, 82(6), 1456-1481. https://doi.org/10.1111/obes.12377

Lengyel, I. \& Varga, A. (2018). A magyar gazdasági növekedés térbeli korlátai - helyzetkép és alapvető dilemmák. Közgazdasági Szemle, 65(5), 499-524. https://doi.org/10.18414/ksz.2018.5.499

Li, X. \& Liu, X. (2005). Foreign Direct Investment and Economic Growth: An Increasingly Endogenous Relationship. World Development, 33(3), 393-407. https://doi.org/10.1016/j.worlddev.2004.11.001

Lucas, R. E. (1988). On the mechanics of economic development. Journal of Monetary Economics, 22(1), 3-42. https://doi.org/10.1016/0304-3932(88)90168-7

Mah, J. S. (2000). An empirical examination of the disaggregated import demand of Korea - the case of information technology products. Journal of Asian Economics, 11, 237-244. https://doi. org/10.1016/s1049-0078(00)00053-1

Mahmoodi, M. \& Mahmoodi, E. (2016). Foreign direct investment, exports and economic growth: Evidence from two panels of developing countries. Economic Research-Ekonomska Istrazivanja, 29(1), 938-949. https://doi.org/10.1080/1331677X.2016.1164922

Mano-Bakalinov, V. (2016). Trade liberalisation and economic growth in Macedonia. South East European Journal of Economics and Business, 11(2), 48-60. https://doi.org/10.1515/jeb-2016-0010

Mencinger, J. (2003). Does foreign direct investment always enhance economic growth? Kyklos, 56(4), 491-508. https://doi.org/10.1046/j.0023-5962.2003.00235.x

MNB (2016). A külföldiek magyarországi közvetlentöke-befektetés állományának végsö befektetők szerinti bontása (MNB Módszertani jegyzet). Magyar Nemzeti Bank.

Nair-Reichert, U. \& Weinhold, D. (2001). Causality tests for cross-country panels: A new look at FDI and economic growth in developing countries. Oxford Bulletin of Economics and Statistics, 63(2), 153-171. https://doi.org/10.1111/1468-0084.00214

Neto, D. G. \& Veiga, F. J. (2013). Financial Globalization, Convergence and Growth: The Role of Foreign Direct Investment. Journal of International Money and Finance, 37, 161-186. https://doi. org/10.1016/j.jimonfin.2013.04.005 
Nkoro, E. \& Uko, A. K. (2016). Autoregressive Distributed Lag (ARDL) cointegration technique: application and interpretation. Journal of Statistical and Econometric Methods, 5(4), 63-91.

OECD (2002). Foreign direct investment for development: Maximising benefits, minimising costs. OECD Publishing. https://doi.org/10.1787/9789264199286-en

OECD (2008). OECD Benchmark Definition of Foreign Direct Investment - Fourth Edition - 2008. OECD Publishing. https://doi.org/10.1787/9789264045743-en

Oudat, M. S., Alsmadi, A. A., \& Alrawashded, N. M. (2019). Foreign direct investment and economic growth in Jordan: an empirical research using the bound test for cointegration. Revista Finanzas $y$ Politica Economica, 11(1), 55-63. http://doi.org/10.14718/revfinanzpolitecon.2019.11.1.4

Patterson, K. (2011). Unit Root Tests in Time Series Volume 1. In Unit Root Tests in Time Series Volume 1. Palgrave Macmillan. https://doi.org/10.1057/9780230299306

Patterson, K. (2012). Unit Root Tests in Time Series Volume 2. In Unit Root Tests in Time Series Volume 2. Palgrave Macmillan. https://doi.org/10.1057/9781137003317

Pegkas, P. (2015). The impact of FDI on economic growth in Eurozone countries. Journal of Economic Asymmetries, 12(2), 124-132. https://doi.org/10.1016/j.jeca.2015.05.001

Pesaran, M. H. \& Shin, Y. (1999). An Autoregressive Distributed-Lag Modelling Approach to Cointegration Analysis. In Econometrics and Economic Theory in the 20th Century (371-413). Cambridge University Press. https://doi.org/10.1017/ccol521633230.011

Pesaran, M. H., Shin, Y., \& Smith, R. J. (2001). Bounds testing approaches to the analysis of level relationships. Journal of Applied Econometrics, 16(3), 289-326. https://doi.org/10.1002/jae.616

Petr, H. \& Bal-Domanska, B. (2016). Impact of Foreign Direct Investment on Economic Growth in Central and Eastern European Countries. Engineering Economics, 27(3), 294-303. https://doi. org $/ 10.5755 /$ j01.ee.27.3.3914

Phillips, P. \& Ouliaris, S. (1990). Asymptotic Properties of Residual Based Tests for Cointegration. Econometrica, 58(1), 165-193. https://doi.org/10.2307/2938339

Phillips, P. \& Perron, P. (1988). Testing for a unit root in time series regression. Biometrika, 75(2), 335-346. https://doi.org/10.1093/biomet/75.2.335

Phouthakannha, N. \& Eungoo, K. (2019). The Effects of Foreign Direct Investment and Economic Absorptive Capabilities on the Economic Growth of the Lao People's Democratic Republic. Journal of Asian Finance, Economics and Business, 6(3), 151-162. https://oi.org/10.13106/ jafeb.2019.vol6.no3.151

Ramsey, J. B. (1969). Tests for Specification Errors in Classical Linear Least-Squares Regression Analysis. Journal of the Royal Statistical Society: Series B (Methodological), 31(2), 350-371. https://doi.org/10.1111/j.2517-6161.1969.tb00796.x

Rebelo, S. (1991). Long-run policy analysis and long-run growth. Journal of Political Economy, 99(3), 500-521. https://doi.org/10.1086/261764

Romer, P. M. (1986). Increasing Returns and Long-Run Growth. Journal of Political Economy, 94(5), 1002-1037. https://doi.org/10.1086/261420

Romer, P. M. (1990). Endogenous Technological Change. Journal of Political Economy, 98(5), S71S102. https://doi.org/10.1086/261725

Royston, P. (1992a). Approximating the Shapiro-Wilk W-test for non-normality. Statistics and Computing, 2(3), 117-119. https://doi.org/10.1007/BF01891203

Royston, P. (1992b). Comment on sg3.4 and an Improved D'Agostino Test. Stata Technical Bulletin, 1(3), 23-24.

Saleem, H., Shabbir, M. S., \& Bilal Khan, M. (2020). The short-run and long-run dynamics among FDI, trade openness and economic growth: using a bootstrap ARDL test for co-integration in selected South Asian countries. South Asian Journal of Business Studies, 9(2), 279-295. https:// doi.org/10.1108/sajbs-07-2019-0124 
Sass, M., Gubik, A. \& Szunomár, Á. (2019). Ázsiai tőkebefektetések Magyarországon-Miért érkeznek gyakran közvetítő országokon keresztül? Statisztikai Szemle, 97(11), 1050-1070. https://doi. org/10.20311/stat2019.11.hu1050

Sass, M. \& Kalotay, M. (2012). Hungary: inward FDI and its policy context. In K. P. Sauvnt, P. Mallampally, \& G. McAllister (Eds.), Inward and outward FDI country profiles (2nd ed., pp. 226245). Vale Columbia Center on Sustainable International Investment, New York, USA. https://doi. org/10.7916/D8DF6P9T

Schneider, P. H. (2005). International trade, economic growth and intellectual property rights: A panel data study of developed and developing countries. Journal of Development Economics, 78(2), 529-547. https://doi.org/10.1016/j.jdeveco.2004.09.001

Shapiro, S. S. \& Wilk, M. B. (1972). An Analysis of Variance Test for the Exponential Distribution (Complete Samples). Technometrics, 14(2), 355-370. https://doi.org/10.1080/00401706.1972.1048 8921

Simionescu, M., Lazányi, K., Sopková, G., Dobeš, K., \& Balcerzak, A. P. (2017). Determinants of Economic Growth in V4 Countries and Romania. Journal of Competitiveness, 9(1), 103-116. https://doi.org/10.7441/joc.2017.01.07

Sirag, A., SidAhmed, S., \& Ali, H. S. (2018). Financial development, FDI and economic growth: evidence from Sudan. International Journal of Social Economics, 45(8), 1236-1249. https://doi. org/10.1108/ijse-10-2017-0476

Solow, R. M. (1956). A contribution to the theory of economic growth. Quarterly Journal of Economics, 70(1), 65-94. https://doi.org/10.2307/1884513

Sothan, S. \& Zhang, X. (2017). Causality between foreign direct investment and economic growth for Cambodia. Cogent Economics \& Finance, 5(1), 1-13. https://doi.org/10.1080/23322039.2016.127 7860

Soylu, Ö. B. (2019). Do foreign direct investment and savings promote economic growth in Poland? Economics and Business Review, 5(19), 3-22. https://doi.org/10.18559/ebr.2019.4.1

Sultanuzamman, R., Fan, H., Akash, M., Wang, B., \& Shakij, U. S. (2018). The role of FDI inflows and export on economic growth in Sri Lanka: An ARDL approach. Cogent Economics \& Finance, 6(1), 1-17. https://doi.org/10.1080/23322039.2018.1518116

Sylwester, K. (2005). Foreign direct investment, growth and income inequality in less developed countries. International Review of Applied Economics, 19(3), 289-300. https://doi. org/10.1080/02692170500119748

Tang, D. (2015). Has the Foreign Direct Investment Boosted Economic Growth in the European Union Countries? Journal of International and Global Economic Studies, 8(1), 21-50.

Tang, C. F. \& Abosedra, S. (2014). Small sample evidence on the tourism-led growth hypothesis in Lebanon. Current Issues in Tourism, 17(3), 234-246. https://doi.org/10.3390/economies6010019

Tang, T. C. \& Nair, M. (2002). A cointegration analysis of Malaysian import demand function: reassessment from the bound test. Applied Economics Letters, 9, 293-296. https://doi. org/10.1080/13504850110073471

Tőkés, L. (2019a). A Magyarországra áramló külföldi müködő tőke ciklikus viselkedése. Statisztikai Szemle, 97(4), 387-408. https://doi.org/10.20311/stat2019.4.hu0387

Tókés, L. (2019b). The effect of foreign direct investment on firm labor productivity: Does the country of origin of the FDI matter? Society and Economy, 41(2), 227-243. https://doi. org/10.1556/204.2019.002

Turner, P. (2006). Response surfaces for an F-test for cointegration. Applied Economics Letters, 13(8), 479-482. https://doi.org/10.1080/13504850500401726

Vojtovič, S., Klimaviciene, A., \& Pilinkiene, V. (2019). Linkages between economic growth and FDI in CEE countries. Ekonomický časopis (Journal of Economics), 67(3), 264-279.

White, H. (1980). A Heteroskedasticity-Consistent Covariance Matrix Estimator and a Direct Test for Heteroskedasticity. Econometrica, 48(4), 817-838. https://doi.org/10.2307/1912934 
Wooldridge, J. M. (2008). Introductory Econometrics, A Modern Approach. 4th edition. South-Western College Cengage Learning.

Yeyati, E. L., Panizza, U., \& Stein, E. (2007). The Cyclical Nature of North-South FDI Flows. Journal of International Money and Finance, 26(1), 104-130. https://doi.org/10.1016/j.jimonfin.2006.10.012

Zandile, Z. \& Phiri, A. (2019). FDI as a contributing factor to economic growth in Burkina Faso: How true is this? Global Economy Journal, 19(1), 1-27. https://doi.org/10.1142/S2194565919500040

Zivot, E. \& Andrews, D. W. K. (1992). Further Evidence on the Great Crash, the Oil-Price Shock, and the Unit-Root Hypothesis. Journal of Business \& Economic Statistics, 10(3), 251. https://doi. org/10.2307/1391541 